\title{
Téoros
}

Revue de recherche en tourisme

\section{Éléments bibliographiques}

\section{Daniel Dumas}

Volume 5, numéro 3, novembre 1986

La gestion touristique : les nouvelles technologies

URI : https://id.erudit.org/iderudit/1080542ar

DOI : https://doi.org/10.7202/1080542ar

Aller au sommaire du numéro

Éditeur(s)

Université du Québec à Montréal

ISSN

0712-8657 (imprimé)

1923-2705 (numérique)

Découvrir la revue

Citer ce document

Dumas, D. (1986). Éléments bibliographiques. Téoros, 5(3), 39-40.

https://doi.org/10.7202/1080542ar d'utilisation que vous pouvez consulter en ligne.

https://apropos.erudit.org/fr/usagers/politique-dutilisation/ 


\title{
Éléments bibliographiques
}

\author{
par Daniel Dumas*
}

La présente liste bibliographique présente quelques références supplémentaires pour poursuivre le débat ou la recherche sur trois thèmes présentés dans ce numéro de Téoros: la gestion touristique, le marketing et les nouvelles technologies. Étant donne l'étendu et la diversitế des problèmes, des plus généraux aux plus particuliers, soulevés par la gestion touristique, il était impossible de prétendre à l'exhaustivité dans ce cadre limité. La liste est donc sélective: on

y trouvera en priorité des textes de nature générale et théorique représentant les principales tendances actuelles. Ont été exclus par exemple les ćtudes de cas trop specifiques ou détaillées, les textes plutôt techniques et finalement tout le domaine plus spécialisé de la gestion et du marketing dans les secteurs de l'hébergement et des agences de voyages. $f$

\section{Daniel Dumas}

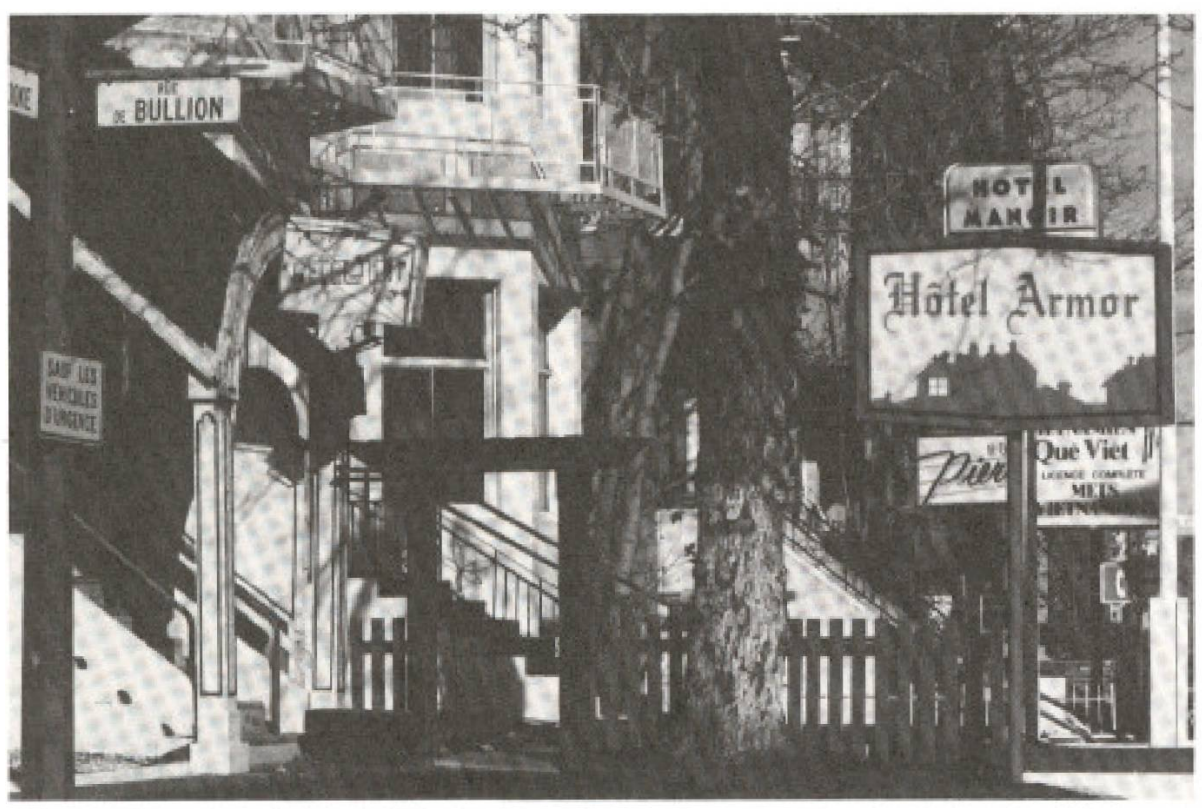

Gérer le rêve

\section{Gestion touristique Généralités}

ASSOCIATION INTERNATIONALE D'EXPERTS SCIENTIFIQUES DU TOURISME, Les problèmes de management dans le domaine du tourisme, Berne: Gurten, $1976,385 \mathrm{p}$.

ASSOCIATION MONDIALE POUR LA FORMATION PROFESSIONNELLE TOURISTIQUE, Le management dans l'industrie touristique et hótelière, $144 \mathrm{p}$.

"Daniel Dumas est bibliothecaire au Centre d'études du tourisme.
BELGAT, Abdu, "La gestion participative"., Espaces, no 75 (août 1985), pp. $18-20$.

BUREAU INTERNATIONAL DU TOURISME SOCIAL, Gestion des associations de tourisme social, Bruxelles: BITS, $1982,24 \mathrm{p}$.

BURKART, A.J. and S. MEDLIK, The Management of Tourism: a Selection of Readings, London: Heinemann, 1975 , $237 \mathrm{p}$.

CANTER, David, "Psychology and Tourism Management", Tourism Management, vol. 3, no 3, (September 1982), pp. 193-195
KEEGAN, Brendan M., "Managerial Leadership: The Hospitality Industrys Response to the New York Aesthetic", Journal of Travel Research, vol. XXI, no 2 (Fall 1982), pp. 10-13,

LANQUAR, Robert, La gestion des ressources humaines dans l'entreprise touristique, Aix-en-Provence, C.H.E.T., 1973

LUNDBERG, Donald E., The Tourist Business, Boston: Cahners Books, 1974, $304 \mathrm{p}$.

MC INTOSH, Robert W., Tourism: Principles, Practices, Philosophies, Columbus (Ohio): Grid Inc, 1977, 283 p.

MILL, Robert Christie and Alaistar M. MORRISON, The Tourism System, Englewood Cliffs (N.J.): Prentice-Hall Inc., 1985, $457 \mathrm{p}$.

PIZAM, Abraham (ed), "The Management of Tourism" (Special Issue), Annals of Tourism Research, vol. VII, no 3(1980), pp. 337-471.

RITCHIE, J.R. Brent, "Tourism Manage" ment Infomation Systems = Conceptual and Operational lssue ${ }^{\text {" }}$, in Tourism Marketing and Management Issues, Washington D.C.: George Washington University, 1980, pp. 337-356.

SCHWANINGER, Markus, "Sirategic Business Management in Tourism", Tourism Management, vol. 7, no 2, (June 1986), pp. 74-85.

SOOD, James H., "The Small Business Administration and Tourism in the $1980 \mathrm{~s}^{\mathrm{s}}$, in Tourism Marketing and Management Issues, Washington D,C : George Washington University, 1980 , pp. 23-32.

WOODSIDE, A.G.. and Ilkka RONKAINEN, "Tourism Management Strategies for Competitive Vacation ", in Tourism Marketing and Management Issues, Washington D.C.: George Washington University, 1980, pp. 3-22. 


\section{Approches du marketing touristique}

"La mercatique touristique" " (numéro spécial), Espaces, no 65 (décembre 1983).

"Le marketing touristique: perspectives et limites" (numéro spécial), Téoros, vol. 3, no 1 (mars 1984).

ASSOCIATION INTERNATINALE D'EXPERTS SCIENTIFIQUES DU TOURISME, Tourisme et marketing, Berne: Gurnen, 1973.

BITNER, M.J., and B.H. BOOMS, "Trends in Travel and Tourism Marketing: the Chaming Structure of Distribution Channels" "Journal of Travel Research, vol. XX, no 4 (Spring 1982), pp. 3944

BARETJE, Rend et Pierre DEFERT, "Promotion et publicie: la commercialisation du tourisme" in Aspects économiques du tourisme, Paris: Berger-Levrault, 1972, pp. 151-169.

BHATIA, A.K.. "Tourism Marketing" and "Tourism Promotion", in Tourism Development: Principles and Practices, New-Delhi: Sterling Publishers, 1983, pp. 134-186.

BONNET, Jeremy, "Implications of Marketing and Promotion for the development of Tourism, Tourism Management, vol. 3, no 4 (1982), pp, 242-247.

BURKART, A.J. and S. MEDLIK. "Marketing in Tourism" " in Tourism: Past, Present and Future, London: Heineman, 1974. pp. 191-216.

CANADA. Ministere de l'expansion industrielle régionale. Tourisme. "Questions en lirige du marketing: expose sur la commercialisation ", in Conférence nationale du tourisme de demain, Ottawa, MEIR, 1985 .

DA VISON, Thomas Lea, "Marketing Travel in an Emerging Economy", Journal of Trayel Research, vol. XXII, no 4 (Spring 1984), pp. 38-39.

FILIATRAULT, Pierre, Marketing touristique, Montréal: Association technique du tourisme, 1981.

HAWKINS, Donald E. and al., Tourism Marketing and Management Issues, Washington, D.C.: George Washington University, 1980, $409 \mathrm{p}$.

HENEGHAN, Philip, Resource Allocation in Tourism Marketing. London: Tourism International Press, 1976, 64 p

KAISER, Charles and Larry C. Helver, "Marketing", in Tourism Planning and Development, Boston: CBI Publishing Inc., 1978, pp, 216-230
KAYNAK, Erdener and James A. MACAULAY, "The Delphi Technique in the Measurement of Tourism Market Potential", Tourism Management, vol. 5 no 2 (June 1985). pp. 87-101.

KAYNAK, Erdener, "Developing Marketing Strategy for a Resource-based Industry" , Tourism Management, vol. 6 , no 3, (September 1985), pp. 184-193

KRIPPENDORF, Jost, Marketing et tourisme, Berne: Hebert Lang \& Cie, 1971, $158 \mathrm{p}$.

LANQUAR, Robert et Robert HOLLIER, Le marketing touristique, Paris: P.U.F. 1981,127 p. (Que sais-je?)

MIDDLETON, Victor T.C., "Tourism Marketing and Product Implications", International Tourism Quaterly, no 3 $(1979)$, pp, $36-46$

NEW-YORK STATE DEPARTMENT OF COMMERCE, The Selling of NewYork: The "I love New-York" program for Tourism, New-York: N.Y.S.D.C., 1983.

PACIFIC AREA TOURISM ASSOCIATION, An Introduction to Marketing and its Application to Tourism. PATA, 1973. $97 \mathrm{p}$.

PAQUETTE, Luc, Le secteur tourisme: avenues en manières de promotion et de commercialisation, Montréal: RONLQ, 1985, $61 \mathrm{p}$.

ROVELSTAD, James M. Behavior-Based Marketing Strategies for Travel and Tourism: The West Virginia Model, West-Virginia University, Bureau of Business Reseatch, 1975.

ROVELSTAD, James $M_{\text {. }}$ and Suzanne POFF-BLA YER, "Research and Sirategic Marketing in Tourism: A Status Report", Journal of Travel Research, vol. XXII, no 2 (Fall 1983), pp. 2-7.

SCHMOLL, G.A., Tourism Promotion, London: Tourism International Press, $1977,136 \mathrm{p}$

SCHWARY, Jean-Jacques, Pour une approche marketing de la promotion touristique, Lausanne: s.n., 1984, 112 p.

TAYLOR, Gotdon D., "How to match plant with demand: a matric for marketing ", Tourism Management, vol. 1, no $1,(1980)$, pp. 56-60.

TOMATIS, Joseph, "L opération micromarche; wn exemple de circuit court de la promoiton touristique" ". Espaces, no 73 (avril 1985), pp. 40-41.

WAHAB, CRAMPTON and ROTHFIELD, Tourism Marketing, London: Tourism International Press, 1976.
WILLIS, Eric, "Low Cost Microcomputers and Tourism Marketing ", Tourism Management, vol. 5, no 3 (September 1984), pp. 236-237

YACOUMIS, John, "Printed Communications Tools in Destination Marketing". International Tourism Quaterly, no 1 (1980), pp. 52-65.

\section{Tourisme et nouvelles technologies}

ANGLADE, Bernard, "Perspectives sur les motivations des lélemateurs touristiques", Espaces, no 69 (aout 1984), pp. $9-11$.

BARRE, Josquin, "Matriser la telematque touristique (1ère et 2ième partie)" , Espaces, no 69 (août 1984) pp. 12-17 et no 70 (octobre 1984) pp. $18-23$.

BARRE, Josquin, "Teléréservation: la cohabitation" "Espaces, no 80 (juin 1986), pp. 9-13.

BARRE, Josquin, "Ou'y $a-t-i l$ dans un système de réservation ", Espaces, no 79 (avril 1986?, pp, 21-24.

BRUCE, Margaret, "Information Technology: Changes in the Travel Trade" ". Tourism Management, vol. 4, no 4, (December 1983), pp. 290-295.

GUDBRANSON, C.G., Report on New Technologies and their Potential to, and Impact on, the Tourism Sector, Etobicoke: Evans Research Corporation, 1983 , 57 p. + annexes.

JULIEN, G, "L'utilisation de la télématique dans le developpement touristique régional", Espaces, no 69 (août 1984), pp. 15-18.

ORGANISATION MONDIALE DU TOURISME, Groupe de travail sur tourisme et télématique, Madrid: OMT, $1985,24 \mathrm{p}$.

TEICHER, James S.. The Telecommunications Revolution (Part I and Part II)", The Cornell Hotel and Restaurant Administration Quaterly, vol. 22, no 4 (February 1982), pp. 12-16, and vol. 23. no 1 (May 1982), pp. 52-56.

VAR, Turgut and al., "Tourism and Computers: Quo Vadis?" Annals of Tourism Research, vol. 13, no 1 (1986), pp. 109-117.

VARLOOT, M.-J., "Telecommunications" et developpement de la telematique touristique" "Espaces, no 69 (août 1984). pp. 6- $\overline{7}$. 